\title{
The relative profitability of calf rearing and bull beef finishing
}

\author{
A.W.A. ORMOND ${ }^{1}$, P.D. MUIR ${ }^{2}$ and C. J. FUGLE ${ }^{2}$ \\ ${ }^{1}$ Nurse \& Ormond, P O Box 115, Waipukurau \\ Te Umuopua Station, RD1, Waipukurau \\ ${ }^{2}$ AgResearch Poukawa Research Station, P O Box 144, Havelock North \\ awao@xtra.co.nz
}

\section{Abstract}

Calf rearing is capital intensive, has high risks associated with animal health and is a short term intense activity. It occurs at a time of the year when out-of-season procurement premiums reflect slow processing throughput, rather than the market outlook for beef. In addition, schedules for bobby calves are announced only one week prior to processing which gives the market little time to settle on costs and the margin for calf rearing.

This paper looks at viability for rearing and finishing and seeks to define margins for both sectors. This has been calculated using a margin per calf reared to $100 \mathrm{~kg}$ and a margin per week for the finisher. Calf rearing is a prescriptive feeding regime in a housed facility, where the performance range is small - i.e calves reach $100 \mathrm{~kg}$ liveweight in 12 weeks. By contrast, bull finishing extends over 1 to 2 years, depends on pastures produced in a wide range of climates, topographies and management systems and has a wide range in performance. The major
\end{abstract}

million. Export slaughter numbers of bulls in 2000/01, most of which are of dairy origin, were 616,000 compared to 479,000 steers. In 1996/97 these figures were 345,000 and 647,000 respectively.

Since 1985 dairy cattle numbers have increased by $38 \%$ compared to an increase of $7 \%$ in the beef sector. Over the same period sheep numbers have fallen by $34 \%$. Dairy calf retentions (Table 1) were consistently in excess of 700,000 in the early 1990's, but when bull schedules fell sharply in 1995, rearers suffered financial losses having reared large numbers of calves without sale contracts. As a result many rearers left the industry. In 1995 the Beef Action Committee was formed by processing companies who were concerned that the 377,000 calves reared that season would provide inadequate future throughput and result in plant closures. In 1996 the Poukawa calf rearing project was initiated to look at low cost systems for calf rearing (Muir et al. 2000).

Table 1 Historical relationship between dairy calf retentions and bull export value.

\begin{tabular}{llllllllll}
\hline & $91 / 92$ & $92 / 93$ & $93 / 94$ & $94 / 95$ & $95 / 96$ & $96 / 97$ & $97 / 98$ & $98 / 99$ & $99 / 00$ \\
\hline Estimated Dairy Calf Retentions & 725 & 729 & 902 & 844 & 377 & 373 & 483 & 492 & 543 \\
Export prices (c/kg) Bull (all weights) & 285.5 & 295.1 & 266.6 & 225.5 & 184.1 & 189.5 & 230.8 & 261.8 & 325.2 \\
\hline
\end{tabular}

Source: New Zealand Meat and Wool Boards Economic Service.

factor impacting on margins in both sectors is the bull schedule. Hence an analysis has been undertaken to look at the impact on both sectors and provide a more equitable basis for establishing the value of the $100 \mathrm{~kg}$ calf.

The market might not accept the model, but the discussion generated is likely to go some way towards resolving the unsatisfactory status quo position where the decision to rear calves has to be made before $100 \mathrm{~kg}$ contract prices are established in the market.

Keywords: beef finishing, bobby calves, bull schedule, calf milk replacer, calf rearing, margins, procurement premium, whole milk

\section{Introduction}

The New Zealand beef industry is increasingly dependant on the dairy sector as a source of crossbred females and surplus male calves. The Meat and Wool Boards Economic Service data shows that since 1989-90 total dairy cattle numbers have risen from 3.3 million to 4.5

\section{Rearing costs}

The fixed and variable costs of rearing have been well established from 5 years of work within the Poukawa calf rearing project and from a survey of calf rearers. The rearing costs and margin outlined in Table 2 are those that can be expected to be incurred by a rearer following the once-a-day milk feeding system described by Muir et al. (2002). The total direct costs associated with calf rearing are expected to be $\$ 250$ in 2002. Of this, $\$ 105$ (42\%) is likely to be the cost of the 4-day-old calf. A further $\$ 111$ (44\%) is likely to be incurred in purchasing feed inputs. Assuming the sale price for a $100 \mathrm{~kg}$ calf is $\$ 330$, the margin available to a rearer amounts to $\$ 81$. Calf prices are very sensitive to supply, with early calves (reaching $100 \mathrm{~kg}$ prior to November) commanding a premium. Calves which reach $100 \mathrm{~kg}$ in December are usually significantly discounted.

Calf rearing is seen as an attractive intensification option to farmers with limited land area and to "lifestyle" farmers 
Table 2 Calf rearing costs and margin model.

\begin{tabular}{|c|c|c|c|c|c|}
\hline \multicolumn{3}{|c|}{1 Costs } & \multirow[t]{2}{*}{$\mathrm{kg} / \mathrm{hd}$} & Total kg & $\$ \mathrm{per} / \mathrm{hd}$ \\
\hline 2 & Calf price & & & & 85 \\
\hline 3 & Procurement costs & & & & 20 \\
\hline 4 & CMR ( premium ) & $\$ /$ bag $(20 \mathrm{~kg})$ & 19.1 & 4775 & 66.85 \\
\hline & Meal (20\% protein) & $\$ /$ bag $(25 \mathrm{~kg})$ & 21.5 & 2150 & 6.57 \\
\hline & Meal (15\% protein) & $\$ /$ bag $(25 \mathrm{~kg})$ & 52.5 & 13125 & 37.34 \\
\hline & Animal health & & & & 5.00 \\
\hline & Bedding & & & & 3.00 \\
\hline 5 & Housing & & & & 10.00 \\
\hline & Straw & & & & 2.00 \\
\hline & Power & & & & 2.50 \\
\hline & Tags (as per AHB) & & & & 1.55 \\
\hline & Deaths \% & 3.0 & & & 6.60 \\
\hline 6 & Interest \% & 8.0 & & & 2.20 \\
\hline & Total rearing costs & & & 248.61 & \\
\hline & Price for $100 \mathrm{~kg}$ calf & & & & 330 \\
\hline & Rearer margin & & & & $\$ 81.39$ \\
\hline $\begin{array}{l}2 . \\
4\end{array}$ & $\begin{array}{l}\text { Inputs and calf price } \\
\text { Bobby calf prices set } \\
\text { Procurement costs in } \\
\text { CMR - calf milk repl } \\
\text { Housing is a depreci } \\
\text { Interest is based on }\end{array}$ & $\begin{array}{l}\text { vary with regio } \\
\text { it } \$ 64 \text { for a } 20 \\
\text { lude delivery to } \\
\text { er. } \\
\text { ion cost. } \\
\text { st of calf plus }\end{array}$ & $\begin{array}{l}\text { carca } \\
\text { earer. }\end{array}$ & 7 & \\
\hline
\end{tabular}

Table 3 Weekly finishing margins.

\begin{tabular}{|c|c|c|c|c|c|c|}
\hline \multirow[t]{3}{*}{ Variables: } & \multirow[t]{3}{*}{$\begin{array}{l}\text { Weeks } \\
\text { Interest (as decimal) } \\
\text { Carcass Weight }(\mathrm{kg}) \\
\text { Levy }(\$)\end{array}$} & \multicolumn{5}{|l|}{$\begin{array}{l}69 \\
0.08 \\
246 \\
30.00\end{array}$} \\
\hline & & \multicolumn{5}{|c|}{ Schedule for $240-270 \mathrm{~kg}$ bull $(\$)$} \\
\hline & & 2.60 & 3.00 & 3.20 & 3.40 & 3.60 \\
\hline \multicolumn{7}{|c|}{100 kg Spring born bull price (\$) } \\
\hline & 260 & 4.21 & 5.64 & 6.35 & 7.06 & 7.78 \\
\hline & 280 & 3.89 & 5.32 & 6.03 & 6.74 & 7.46 \\
\hline & 300 & 3.57 & 5.00 & 5.71 & 6.42 & 7.14 \\
\hline & 320 & 3.25 & 4.68 & 5.39 & 6.10 & 6.82 \\
\hline & 340 & 2.93 & 4.36 & 5.07 & 5.78 & 6.49 \\
\hline & 360 & 2.61 & 4.03 & 4.75 & 5.46 & 6.17 \\
\hline & 380 & 2.29 & 3.71 & 4.43 & 5.14 & 5.85 \\
\hline
\end{tabular}

Assumptions:

Weaner bulls are purchased on $15^{\text {th }}$ November @ $100 \mathrm{~kg}$.

Bulls are slaughtered on the $15^{\text {th }}$ of March @ $246 \mathrm{~kg} \mathrm{CW}$.

Interest is charged @ 8\%. Levies are \$30/head.

$2 \%$ deaths.

$\$ 15$ animal health.

$\$ 10$ transport.

who often have little farming experience. As a consequence these rearers may often purchase small or Friesian $x$ Jersey calves in their haste to fill their rearing facilities with calves. A consequence of small calves is a failure to achieve the $100 \mathrm{~kg}$ target weight in time to market these calves to best advantage. Although Friesian $\mathrm{x}$ Jersey calves can still perform well in intensive finishing systems (Muir et al. 2001) there is considerable prejudice against these animals within the beef industry. Consequently these calves are often significantly discounted by the purchaser.

The calf rearer's margin is dependant on the international bobby veal price, the price of feed inputs (calf milk replacers - CMR's and concentrate rations), and the bull schedule. Historically bobby veal schedules were not announced, rather all calves were processed on behalf of dairy farmers by one company (Dairy Meats). Farmers were paid in advance and received an end of season pool payment which reflected market returns. In recent years several meat processing companies have competed for bobby calves resulting in a bobby calf schedule. By 1 July 2002, only Richmond had announced its bobby calf schedule.

Richmond's July 2002 schedule of $\$ 3.20 / \mathrm{kg}$ for a $20 \mathrm{~kg}$ bobby carcass (\$64) has been used to calculate the value of the 4-day-old calf to the rearer. The price for a 40 $\mathrm{kg}$ live weight calf (20 kg carcass weight) of $\$ 85$ to the rearer assumes a \$21 per head premium is paid to the dairy farmer. The premium is for extra care by the dairy farmer to ensure adequate colostrum intake in the first 24 hours and an acknowledgement that some calves will be even heavier than $40 \mathrm{~kg}$ liveweight. It is a requirement in law that all bobby calves slaughtered must have been fed colostrum, but in practice, systems are not well developed on dairy farms to ensure that this occurs. The 2002 season has seen a $\$ 48$ drop in the value of the $20 \mathrm{~kg}$ carcass calf in the Richmond schedule. This has been due to a return to normal in Europe after the Foot and Mouth scare. The September 11 terrorist attack in New York caused a pronounced downturn in demand for veal and the firming New Zealand dollar has also reduced the veal returns.

Feed costs have reduced in 2002 with CMR's reducing by over $20 \%$ down to $\$ 70$ per $20 \mathrm{~kg}$ bag. Vegetable protein CMR's are about $\$ 8 /$ bag cheaper again, but overseas data suggests these increase the risk of digestive problems and require more experience in their use than conventional CMR's This in turn may increase the 
mortality and/or jeopardise calf growth rate. Meal prices have increased from the 2001 season, but over all the feed input costs have declined.

Extensive canvassing of rearers suggests that $\$ 75$ is a benchmark margin, below which they will not rear. This margin can be improved on by substituting CMR with whole milk and/or procuring calves directly from dairy farmers. Industry practice for once-a-day feeding with whole milk involves feeding 2 litres of whole milk morning and night for the first week, followed by feeding 3 litres per day for 5 weeks. The total whole milk required is 119 litres which at 33 cents per litre means the milk feeding component costs $\$ 39.27$, a saving of $\$ 27.50$ over the current CMR price.

\section{Pricing of $100 \mathrm{~kg}$ weaner bulls}

Historically, the sale of $100 \mathrm{~kg}$ Friesian bull calves in November/December has been related to the bull schedule of the day. In other words, if the beef schedule is $\$ 3.20 / \mathrm{kg}$ for a $245-270 \mathrm{~kg}$ bull carcass, then the $100 \mathrm{~kg}$ bull price has been around $\$ 320$. This assumption ties the calf price to a schedule, which reflects significant seasonal procurement premiums and ignores the fact that a significant proportion of bulls are actually slaughtered between February and May when the schedule is significantly lower (Meares \& McKenzie 2002; Figure 1). This method undervalues the calf at high beef schedules and overvalues the calf at low beef schedules (Table 4). Using this "straight line schedule" valuation, the weaner bull price at a schedule of $\$ 2.60$ for the $270 \mathrm{CW}$ bull produces a finishing margin of $\$ 4.21$ per week. At high schedules, for example $\$ 4.00$, the finishing margin increases to $\$ 6.96$ per week.

The assumptions made to determine the finishing margin are that the $100 \mathrm{~kg}$ weaner bull is purchased on the $15^{\text {th }}$ November and grows at $0.78 \mathrm{~kg} /$ day through to slaughter at $246 \mathrm{~kg}$ carcass weight on the $15^{\text {th }}$ March.
Table 4 Schedule method of valuing calves.

\begin{tabular}{ccc}
\hline Schedule & $\begin{array}{c}100 \mathrm{~kg} \\
\text { calf value }(\$)\end{array}$ & $\begin{array}{c}\text { Weekly } \\
\text { finishing margin }(\$)\end{array}$ \\
\hline $245-270 \mathrm{~kg} \mathrm{CW}$ Bull & & \\
2.60 & 260 & 4.21 \\
2.80 & 280 & 4.60 \\
3.00 & 300 & 5.00 \\
3.20 & 320 & 5.39 \\
3.40 & 340 & 5.78 \\
4.00 & 400 & 6.96 \\
\hline
\end{tabular}

Figure 1 North Island net prices for $280 \mathrm{~kg}$ bull compared to market indicator price.

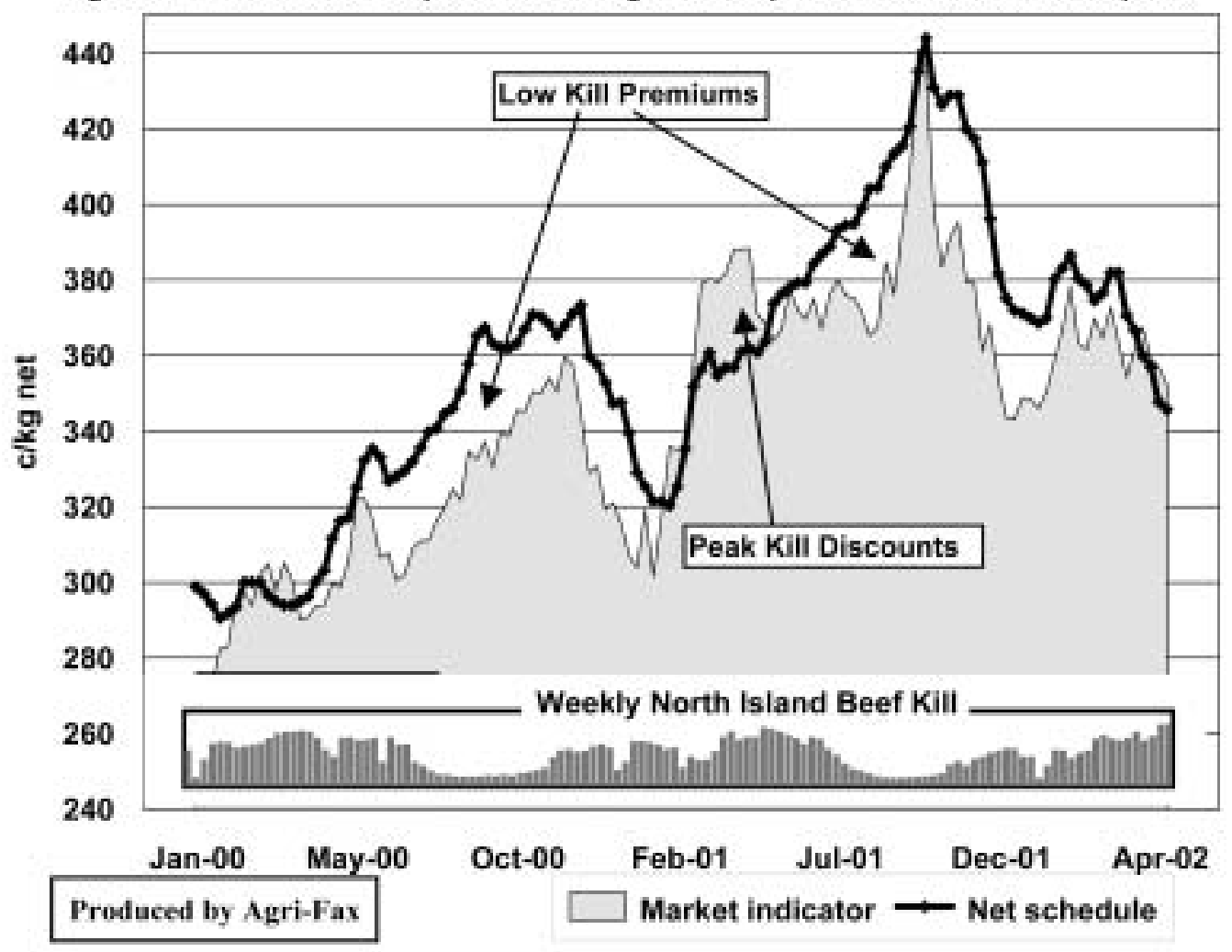


The weight gain and dry matter (DM) consumption are detailed in Appendix 1. Interest is charged at $8 \%$ on the purchase price of the $100 \mathrm{~kg}$ weaner bull, deaths are $2 \%$, levies are charged at $\$ 30 /$ head, transport is $\$ 10$ and animal health costs are assumed to be $\$ 15 /$ head over the 16 months to slaughter.

There will always be debate over the comparable level of performance in calf rearing and finishing and a fair return to both operations. Due to the different nature of each sector, as described, it seems logical to use viability in each sector to establish values for the $100 \mathrm{~kg}$ weaner bulls. It is less important that the market accepts the model than that the existing 'straight line' schedule method be questioned and debate generated.

The high turnover of rearers indicates that many have not made satisfactory margins. A bull reared in the dairy industry has traditionally involved dairy farmers, commission agents, rearers, finishers and processors. It is significant that commissions paid in the life of a bull often exceed the rearer margin. Direct relationships between the dairy farmer, rearer and finisher offer significant cost reductions.

Recent years have seen the emergence of $40-50$ hectare units that rear large numbers, $(2000-6000)$ of calves annually. These operations use a combination of direct purchase and marketing of calves, the use of whole milk and economies of scale to run a successful calf rearing business.

\section{Conclusion}

The historical method of relating the price of $100 \mathrm{~kg}$ calves to the schedule of the day is flawed and undervalues the calf at high beef schedules and overvalues the calf at low beef schedules.

The most recent serious downturn in the beef schedule (1995) was associated with a reduction in calves reared by almost 530,000 . Since then the decline in the beef cow herd has meant that the beef industry has become even more dependent on the supply of calves from the dairy herd. An analysis of finisher and rearing margins indicates that as the schedule for the $245-270 \mathrm{~kg} \mathrm{CW}$ bull reduces towards $\$ 2.50 / \mathrm{kg}$, there is a risk that insufficient dairy beef calves will be reared. More extensive use of contracts or innovative risk sharing by finishers will be required to prevent a shortage of over 250,000 calves.

\section{ACKNOWLEDGMENTS}

The authors are grateful for the wide range of commercial support the project has enjoyed. Past sponsors who have supported the project are the Beef Action Committee, PCL Feeds, Ngahiwi Farms, Kiwi Milk Products and the New Zealand Holstein Friesian Association. Current project sponsors are MEAT NZ, Richmond Ltd, AGMARDT and the MAF Sustainable Farming Fund.

\section{REFERENCES}

Meares, D.W., McKenzie, J.R. 2002. Agri-Fax Ltd, Greta Valley Ltd, RD, North Canterbury. May 2002 Report.

Anon 2002. New Zealand Meat Boards Economic Service. Beef Production Outlook

Geenty, K.G; Rattray, P.V. (1987) The energy requirements of grazing sheep and cattle. New Zealand Society of Animal Production. Occasional Publication No. 10: 39-43.

Muir, P.D.; Nieuwenhuis, G.; Smith, N.B. and Ormond, A.W.A. (2000). A comparison of rearing systems for dairy beef calves. Proceedings of the New Zealand Grassland Association 62: 9-11.

Muir, P.D., Fugle, C.J., Smith, N.B. and Ormond A.W.A. (2001). A comparison of bull beef production from Friesian type and selected Jersey cross type calves. Proceedings of the New Zealand Grassland Association 63: 203-207.

Muir, P.D., Fugle, C.J. and Ormond A.W.A. (2002). Calf rearing using a once-a-day rearing system: current best practice. Proceedings of the New Zealand Grassland Association 64: 21-24.

Appendix 1 Performance assumptions for bull finishing margins.

\begin{tabular}{lcccc}
\hline $\begin{array}{l}\text { Period } \\
60 \text { days to: }\end{array}$ & $\begin{array}{c}\text { Liveweight at end } \\
\text { of period (kg) }\end{array}$ & $\begin{array}{c}\text { Average daily liveweight } \\
\text { gains - ADLWG (kg) }\end{array}$ & $\begin{array}{c}\text { Intakes } \\
\text { kg DM }\end{array}$ & $\begin{array}{c}\text { Total period } \\
\text { intake (kg DM) }\end{array}$ \\
\hline $15 \mathrm{Jan}$ & 145 & 0.75 & 3.2 & 192 \\
$15 \mathrm{Mar}$ & 190 & 0.75 & 4.3 & 258 \\
$15 \mathrm{May}$ & 235 & 0.75 & 5.4 & 324 \\
$15 \mathrm{Jul}$ & 265 & 0.5 & 5.5 & 330 \\
$15 \mathrm{Sep}$ & 325 & 1.0 & 8.4 & 504 \\
$15 \mathrm{Nov}$ & 400 & 1.25 & 10.5 & 630 \\
$15 \mathrm{Jan}$ & 460 & 1.0 & 10.3 & 618 \\
$15 \mathrm{Mar}$ & 490 & 0.5 & 8.6 & 516 \\
\end{tabular}

Average daily DM consumption was $7 \mathrm{~kg}$ DM/day over 483 days. 
Appendix 2 DM consumed(/kg/ha/yr) at various stocking rates based on performance in Appendix 1.

\begin{tabular}{cc}
\hline Bulls/ha & Annual DM consumed \\
\hline 2.0 & 5096 \\
2.5 & 6370 \\
3.0 & 7644 \\
3.5 & 8918 \\
\hline
\end{tabular}

Appendix 3 Finishing returns (cents/kg DM consumed) at various weekly margins based on performance in Appendix 1.

\begin{tabular}{cc}
\hline & $(\$)$ \\
\hline Weekly margin & Finishing returns \\
\hline 4.50 & 9.2 \\
5.50 & 11.2 \\
6.50 & 13.3 \\
7.50 & 15.3 \\
\hline
\end{tabular}

